\title{
Motivasi mahasiswa penerima beasiswa BIDIKMISI Universitas Udayana mengikuti gaya hidup hedonisme
}

\author{
Yuli Endah Purwati Arum Buana dan David Hizkia Tobing \\ Program Studi Sarjana Psikologi, Fakultas Kedokteran, Universitas Udayana \\ davidhizkia@yahoo.com
}

\begin{abstract}
Abstrak
Globalisasi memengaruhi berbagai aspek salah satunya gaya hidup. Gaya hidup hedonisme adalah gaya hidup yang memandang kesenangan dan kenikmatan sebagai tujuan hidup. Masyarakat ekonomi menengah ke atas mudah mengikuti gaya hidup hedonisme karena mempunyai modal kapital yang cukup, sedangkan masyarakat ekonomi menengah ke bawah akan kesulitan karena tidak mempunyai cukup modal. Gaya hidup hedonisme cepat memengaruhi remaja karena pada periode tersebut remaja mudah terpengaruh oleh teman sebaya. Bali sebagai destinasi wisata nomor satu di Indonesia sangat memungkinkan terjadi interaksi warga lokal dan wisatawan mancanegara yang membawa gaya hidup hedonisme, sehingga sangat mungkin remaja Bali menjadi mudah terpengaruh gaya hidup hedonisme. Universitas Udayana sebagai universitas favorit di Bali yang mendapatkan bantuan dana yaitu Biaya Pendidikan Mahasiswa Miskin Berprestasi (BIDIKMISI). Mahasiswa penerima beasiwa BIDIKMISI tidak luput dari pengaruh gaya hidup hedonisme, Studi pendahuluan dilakukan tehadap beberapa mahasiswa penerima beasiswa BIDIKMISI di Universitas Udayana menunjukkan beberapa mahasiswa memiliki kecenderungan gaya hidup hedonisme. Berdasarkan hal tersebut, penelitian ini bertujuan untuk mengetahui motivasi mahasiswa penerima beasiswa BIDIKMISI Universitas Udayana untuk mengikuti gaya hidup hedonisme. Penelitian ini menggunakan metode kualitatif dengan pendekatan fenomenologi. Jumlah responden dalam penelitian ini adalah tujuh orang mahasiswa penerima beasiswa BIDIKMISI di Universitas Udayana. Penelitian ini menghasilkan motivasi mengikuti gaya hidup hedonisme pada mahasiswa penerima beasiswa BIDIKMISI di Universitas Udayana berasal dari dalam diri yaitu percaya diri dan karier kemudian dari luar diri yaitu promosi, kepercayaan, penyetaraan, model, pengakuan, relasi, dan ingin menjadi terkenal.
\end{abstract}

Kata Kunci: BIDIKMISI, hedonisme, mahasiswa, motivasi.

\begin{abstract}
Globalization influences many aspects and one of them is lifestyle. Hedonism is a lifestyle that assume the pleasure and enjoyment are goals of human life. Hedonism Lifestyle usually easier to follow by society with the upper-middle-class background rather than the lower-middle-classes because they have more sufficient capital. The Hedonism Lifestyle is rapidly affects the teenagers because in their adolescent period they easily affected by peers. Bali is one of the most popular tourist destination in Indonesia and that makes a possibility of having a new sight of different lifestyle between the locals and foreign tourist which the foreign mostly brings a Hedonism Lifestyle, and possibly the teenagers will easily influenced by the Hedonism Lifestyle. Udayana University as a favorite university in Bali offers a BIDIKMISI Scholarship Programme which is focusing for students from low-income families with high-achivements. The BIDIKMISI awardees were also influenced by the Hedonism Lifestyle. The preliminary study was conducted on several BIDIKMISI awardees in Udayana University showed that some of the awardees had tendency to live a Hedonism Lifestyle. According to that, this study aimed to know the Motivation of Hedonism Lifestyle within the Awardees of BIDIKMISI in Udayana University. This study used qualitative research with phenomenological approach. This study involved 7 BIDIKMISI awardees in Udayana University as its subjects. This research resulted that self-confidence and career that came from themselves were the Motivation of Hedonism Lifestyle within the Awardees of BIDIKMISI in Udayana University, on the other hand promotion, trust, equality, model, recognition, relation and became a famous person that came from the environment also being the motivation of the Hedonism Lifestyle.
\end{abstract}

Keywords : BIDIKMISI, hedonism, motivation, students. 


\section{LATAR BELAKANG}

Globalisasi adalah proses penyebaran unsur-unsur baru baik berupa informasi, pemikiran, teknologi, maupun gaya hidup secara mendunia. Dewasa ini globalisasi sudah merambah ke seluruh bangsa-bangsa di dunia salah satunya Indonesia. Globalisasi menjadikan dunia atau lingkungan di seluruh dunia berubah menjadi lingkungan kecil yang tanpa batas (Setiadi, 2014).

Globalisasi masuk dan memengaruhi aspek kehidupan individu termasuk sosial ekonomi yang dalam hal ini telah dikatakan meningkatkan taraf hidup masyarakat. Di Indonesia, globalisasi masih menjadi hal yang sangat penting yang dapat dilihat dari pesatnya perkembangan industri yang berkaitan dengan perubahan gaya hidup masyarakat Indonesia (Patricia \& Handayani, 2014).

Gaya hidup adalah pola interaksi seseorang yang diungkapkan dalam aktivitas, ketertarikan, dan pendapat seseorang (Setiadi, 2013). Gaya hidup secara lebih rinci didefinisikan sebagai cara hidup yang diidentifikasikan oleh bagaimana seseorang menghabiskan waktu mereka (aktivitas), apa yang dianggap penting di lingkungannya (ketertarikan) dan apa yang mereka pikirkan tentang diri mereka sendiri serta dunia sekitar (pendapat). Gaya hidup suatu masyarakat akan berbeda dengan masyarakat lainnya, bahkan dari masa ke masa bergerak dinamis (Setiadi, 2013).

Gaya hidup adalah pendorong dasar yang memengaruhi sikap dan kebutuhan individu. Pada zaman ini, gaya hidup sering dihubungkan dengan kelas sosial ekonomi dan menunjukkan citra seseorang. Gaya hidup adalah pola dimana orang hidup dan menghabiskan waktu serta uang (Ajeng, 2010).

Salah satu jenis gaya hidup yang ada adalah hedonisme yang berasal dari bahasa latin yaitu hedon yang memiliki arti sesuatu yang mendatangkan kesenangan (Ajeng, 2010). Dalam Kamus Besar Bahasa Indonesia (KBBI) hedonisme merupakan pandangan yang menganggap kesenangan dan kenikmatan materi sebagai tujuan utama dalam hidup, orangorang yang memiliki pandangan ini menganggap bahwa tujuan untuk hidup adalah bersenang-senang (KBBI, 2008).

Chaney (2010) berpendapat bahwa gaya hidup hedonisme merupakan pola gaya hidup yang lebih mencari kesenangan, seperti menghabiskan waktu di luar rumah, lebih banyak bermain, senang pada keramaian, dan menyukai barangbarang mahal untuk menjadi pusat perhatian. Kegiatan yang mengarah pada gaya hidup hedonisme, misalnya jalan-jalan ke tempat ramai seperti mall, shopping, mencari film baru dan menonton ke bioskop, pesta mode, nongkrong di kafe, karaoke, ikut dalam komunitas motor gede dan mobil, serta aktivitas lain untuk bersenang-senang (Kunto, 2011).

Individu dengan kelas sosial ekonomi menengah ke atas yang menganut gaya hidup hedonisme dapat dikatakan masih dalam batas yang wajar, karena materi yang dimiliki masih mencukupi untuk memenuhi gaya hidupnya dan tidak berdampak bagi orang lain, namun bagaimana dengan individu dengan kelas sosial ekonomi menengah ke bawah yang memaksakan diri untuk bergaya hidup mewah dan mengikuti gaya hidup hedonisme demi memperlihatkan citra dan identitas diri. Dalam perkembangannya, gaya hidup hedonisme cenderung menyerang remaja, karena pada masa remaja individu sedang mencari jati dirinya (Sari, 2014).

Tentu ada hal-hal yang mendorong atau memotivasi para remaja dalam berperilaku atau mengikuti gaya hidup hedonisme seperti keinginan untuk mencapai sesuatu yang berhubungan dengan kesenangan, kebebasan, dan kenikmatan hidup (Trimartati, 2014). Motivasi untuk terus memenuhi kebutuhan akan gaya hidup hedonisme membuat remaja merasa terancam karena kebutuhan akan gaya hidup hedonisme yang bersifat dinamis yaitu selalu mengikuti perkembangan zaman. Remaja akan merasa takut gagal, gelisah, dan tertekan akan stigma yang diberikan oleh orang lain sebagai individu yang tertinggal oleh zaman jika tidak mengikuti tren (Trimartati, 2014).

Dalam artian luas motivasi berasal dari bahasa Latin yaitu movere yang berarti dorongan atau menggerakkan. Motivasi dikatakan penting karena motivasi adalah hal yang menyebabkan, menyalurkan, dan mendukung perilaku manusia (Setiadi, 2013). Motivasi hedonisme adalah dorongan dari dalam atau luar diri untuk memenuhi kebutuhan akan suasana senang dan kenikmatan yang merupakan kecenderungan tujuan hidup kaum hedonis (Paramita, 2015).

Kecenderungan tersebut sangat mudah masuk ke dalam kehidupan kaum remaja, karena pada masa remaja adalah masa dimana rasa ingin tahu memiliki kapasitas yang besar dalam tahapan perkembangan individu (Santrock, 2007). Masa remaja merupakan periode penting dalam rentang kehidupan individu karena merupakan kelompok usia yang berada pada periode transisi perkembangan antara masa kanak-kanak menuju masa dewasa, yang melibatkan perubahan-perubahan biologis, kognitif, dan sosioemosional (Santrock, 2007). Masa remaja berlangsung pada usia 12 sampai 21 tahun untuk wanita, dan 13 tahun sampai 22 tahun bagi laki-laki. Pada masa remaja individu ingin memperlihatkan keunikan yang dimiliki yaitu masa pencarian identitas diri seperti gaya rambut, gaya berpakaian, dan kebanggaan untuk kepemilikan sesuatu yang mewah semata-mata untuk menarik perhatian orang lain. Semua hal tersebut merupakan cara untuk menunjukkan identitas diri yang akan berpengaruh terhadap citra dirinya (Santrock, 2007).

Remaja cenderung ingin mengetahui hal baru dan tidak ragu untuk mencobanya, kemudian remaja juga cepat terpengaruh oleh dunia di luar dirinya seperti iklan, perubahan, dan cenderung boros dalam menggunakan uang yang dimilikinya (Sari, 2009). Masa remaja juga merupakan kesempatan bersosialisasi, dalam kelompok pertemanan untuk memperluas wawasan dibandingkan dengan masa kanakkanak. Hal tersebut menyebabkan remaja ingin terus mengikuti tren, dan ingin memiliki fasilitas yang paling canggih di era saat ini (Sinthia, 2011). 
Mahasiswa merupakan individu yang masuk dalam tahap perkembangan remaja akhir yaitu antara umur 18 sampai 22 tahun. Kecenderungan gaya hidup hedonisme juga tidak luput dari remaja yang berstatus mahasiswa yang tinggal di Indonesia khususnya di kota besar seperti Denpasar, Bali. Universitas Udayana adalah Universitas favorit di Bali yang mempunyai 14 Fakultas dan 104 Program Studi. Mahasiswa di Universitas Udayana juga tidak luput dari pengaruh gaya hidup hedonisme.

Dalam preliminary study yang dilakukan oleh peneliti, menurut Wahyu Budi Nugroho yang merupakan Sosiolog sekaligus dosen di Fakultas Ilmu Sosial dan Ilmu Politik Universitas Udayana, mengatakan jika mahasiswa Universitas Udayana saat ini lebih memilih untuk memenuhi gaya hidup daripada kebutuhan hidup, dan menampilkan eksistensi masyarakat tontonan yang saling menonton satu sama lain, lebih jelasnya yaitu mahasiswa lebih menampilkan simbol pada dirinya dengan mengutamakan "merek" seperti merek pakaian, sepatu, gadget, dan lainlain yang dapat memperlihatkan citra diri dan eksistensi seorang mahasiswa. Hal tersebut dipengaruhi oleh banyaknya mall atau pusat perbelanjaan yang ada di Bali, yang mendorong masyarakat untuk berperilaku konsumtif yang merupakan salah satu ciri-ciri masyarakat yang memiliki kecenderungan gaya hidup hedonisme (Buana \& Tobing, 2017).

Seiring dengan perkembangan pendidikan di Provinsi Bali khususnya kota Denpasar peranan perguruan tinggi sangat penting guna menyiapkan peserta didik menjadi manusia yang memiliki akademik dan profesional untuk menerapkan, mengembangkan, dan menciptakan ilmu pengetahuan. Dalam menjalankan perkuliahan tentunya setiap peserta didik memiliki tanggungan untuk membayar biaya perkuliahan, mahalnya biaya pendidikan pastinya memberatkan para peserta didik yang berlatar belakang status sosial ekonomi menengah kebawah atau dikatakan kurang mampu untuk membayar biaya perkuliahan. Dalam hal ini, pemerintah Indonesia memiliki program bantuan dana yaitu Biaya Pendidikan Mahasiswa Miskin dan Berprestasi (BIDIKMISI) (Kemenristek, 2017).

Berdasarkan studi pendahuluan yang telah dilakukan, menurut Dra. Ni Wayan Wirati yang merupakan Kepala Bagian Kesejahteraan Mahasiswa di Universitas Udayana, BIDIKMISI adalah program beasiswa dari Pemerintah Pusat untuk peserta didik yang berprestasi dan kurang mampu secara ekonomi. Dana bantuan diberikan langsung oleh Presiden Republik Indonesia dari tahun 2010. Program beasiswa BIDIKMISI merupakan salah satu program tingkat nasional yang diberikan untuk peserta didik dalam rentang Diplomasi dan Sarjana. Beasiswa BIDIKMISI diberikan kepada mahasiswa yang memenuhi syarat di 14 Fakultas di Universitas Udayana. Tujuan dari beasiswa BIDIKMISI adalah untuk membantu masyarakat melanjutkan pendidikan di jenjang perkuliahan S1 dan Diploma bagi mahasiswa yang berprestasi dan kurang mampu secara ekonomi. BIDIKMISI juga bertujuan untuk memutuskan mata rantai kemiskinan di
Indonesia khususnya di Provinsi Bali (Buana \& Tobing, 2017).

Bali merupakan destinasi wisata nomor satu di indonesia yang memungkinkan untuk terjadi pertemuan antara warga lokal dan wisatawan mancanegara yang membawa gaya hidup hedonisme sehingga sangat mungkin remaja Bali menjadi lebih mudah terpengaruh gaya hidup hedonisme tersebut (Pitana \& Diarta, 2009).

Universitas Udayana adalah universitas favorit di Bali yang menggunakan layanan beasiswa yaitu BIDIKMISI yang merupakan salah satu bentuk dana bantuan untuk peserta didik yang berprestasi namun sosial ekonominya dikategorikan menengah kebawah atau kurang mampu guna meningkatkan kompetensi, kualifikasi dan keterampilan profesional peserta didik.

Menurut preliminary study yang dilakukan oleh peneliti di Universitas Udayana terhadap mahasiswi yang menerima beasiswa BIDIKMISI melalui wawancara mendalam, didapatkan hasil jika mahasiswi Universitas Udayana yang menerima beasiswa BIDIKMISI memiliki kecenderungan gaya hidup hedonisme yaitu ditinjau berdasarkan tiga aspek dari Amstrong (2003) yaitu aktivitas seperti lebih banyak menghabiskan waktu di luar rumah dengan nongkrong di pusat perbelanjaan atau kafe bersama teman dan orang terdekat, kemudian minat seperti selalu mengikuti tren, mengoleksi barang-barang mewah dan kepemilikan gadget canggih, dan terakhir adalah opini yaitu selalu mengetahui tren atau informasi terkini (Buana \& Tobing, 2017).

Berdasarkan pemaparan tersebut, peneliti tertarik melakukan penelitian mengenai motivasi pada mahasiswa Universitas Udayana yang menerima beasiswa BIDIKMISI untuk mengikuti gaya hidup hedonisme, sehingga peneliti mampu melihat fenomena dari sudut pandang mahasiswa tersebut.

\section{METODE PENELITIAN}

\section{Tipe Penelitian}

Penelitian ini menggunakan metode penelitian kualitatif yaitu penelitian yang bertujuan untuk memahami fenomena tentang apa yang dialami oleh subjek penelitian seperti perilaku, persepsi, motivasi, dan lain-lain. Hal tersebut secara holistik dan deskriptif dirangkum dalam bentuk katakata dan bahasa, pada suatu konteks khusus yang alamiah dan dengan memanfaatkan berbagai metode ilmiah (Moleong, 2016). Metode penelitian kualitatif merupakan metode untuk mengeksplorasi dan memahami makna yang oleh sejumlah individu atau sekelompok orang dianggap berasal dari masalah sosial atau kemanusiaan (Creswell, 2009).

Penelitian ini menggunakan penelitian kualitatif dengan pendekatan fenomenologi. Pendekatan fenomenologi adalah pandangan berpikir yang menekankan pada fokus kepada pengalaman-pengalaman subjektif manusia dan interpretasiinterpretasi dunia (Moleong, 2016). Penelitian kualitatif dengan pendekatan fenomenologi dikatakan sejalan dengan 
penelitian ini karena dilihat dari definisi metode penelitian kualitatif, penelitian ini ingin memahami fenomena dan makna yang dianggap berasal dari masalah sosial atau kemanusiaan yaitu apa yang memotivasi mahasiswa penerima beasiswa BIDIKMISI di Universitas Udayana untuk mengikuti kecenderungan gaya hidup hedonisme. Penelitian kualitatif juga cocok dan sejalan dengan penelitian ini karena mengungkap fenomena kecenderungan gaya hidup hedonisme pada mahasiswa penerima beasiswa BIDIKMISI di Universitas Udayana, yang kemudian dengan pendekatan fenomenologi dianggap sejalan karena menjadikan motivasi mahasiswa untuk mengikuti gaya hidup hedonisme sebagai pusat dari fenomena itu sendiri.

Penelitian ini menggunakan tujuh mahasiswa penerima beasiswa BIDIKMISI Universitas Udayana yang memiliki kecenderungan gaya hidup hedonisme. Secara terperinci karakteristik responden yang dilibatkan dalam penelitian ini adalah sebagai berikut.

1. Remaja yang berusia 18-22 tahun yang termasuk dalam kategori remaja akhir

2. Berdomisili di Bali

3. Masih berstatus mahasiswa di Universitas Udayana

4. Penerima bantuan dana beasiswa BIDIKMISI

5. Mengikuti gaya hidup hedonisme

\section{Tempat Penelitian}

Tempat penelitian akan dilakukan di Denpasar, karena subjek banyak melakukan aktivitas perkuliahan di Universitas Udayana Denpasar. Hal tersebut untuk memudahkan proses pengumpulan data.

\section{Teknik Penggalian Data}

\section{Wawancara}

Wawancara adalah percakapan dengan tujuan tertentu, percakapan dalam wawancara dilakukan oleh dua pihak, yaitu pewawancara (interviewer) dan orang yang akan diwawancara (interviewee) (Moleong, 2016). Sugiyono (2016) menjelaskan jika dalam sesi wawancara dua orang bertemu untuk bertukar informasi dan ide melalui tanya jawab, sehingga dapat dikonstruksikan makna dalam suatu topik tertentu. Penelitian ini menggunakan metode wawancara mendalam (in-depth interview) dan wawancara semi terstruktur. Wawancara mendalam adalah tanya jawab yang bersifat terbuka untuk memperoleh data tentang maksud subjek, bagaimana subjek menggambarkan dunia dan bagaimana subjek menjelaskan dan menyatakan perasaan terkait kejadian penting dalam kehidupan subjek. Wawancara semi terstruktur adalah wawancara yang dilakukan dengan menggunakan garis-garis besar pertanyaan, dalam pelaksanaannya lebih bebas dibandingkan dengan wawancara terstruktur. Tujuan dari wawancara jenis ini adalah untuk menemukan permasalahan secara lebih terbuka (Sugiyono, 2016).

Teknik wawancara dalam penelitian ini dilakukan dengan dialog langsung dengan subjek yang sesuai dengan karakteristik yang telah ditentukan untuk menggali informasi dan memperoleh data mengenai motivasi mahasiswa penerima beasiswa BIDIKMISI di Universitas Udayana untuk mengikuti gaya hidup hedonisme.

Observasi

Observasi adalah salah satu teknik pengambilan data dalam penelitian kualitatif. Observasi dilakukan untuk membantu peneliti lebih memahami konteks data dalam keseluruhan situasi sosial, jadi akan dapat diperoleh pandangan yang holistik atau menyeluruh (Sugiyono, 2016). Penelitian ini menggunakan jenis observasi partisipatif pasif yaitu observasi yang mana peneliti datang ke tempat suatu peristiwa atau aktivitas yang diamati berlangsung, tetapi tidak ikut terlibat dalam kegiatan tersebut (Sugiyono, 2014). Pada penelitian ini, peneliti akan melakukan observasi selama proses wawancara berlangsung, dan data hasil observasi selanjutnya disajikan dalam bentuk fieldnotes yaitu catatan lapangan yang dibuat setelah dari lapangan yang telah dirangkai atau disusun berdasarkan kata-kata kunci, frasa, pokok-pokok isi pembicaraan atau pengamatan, mungkin gambar, sketsa, sosiogram, diagram, dan lain-lain (Moleong, 2016). Dalam penelitian ini, catatan lapangan akan dilengkapi dengan menggunakan alat tambahan yaitu rekaman audio. Hal tersebut bertujuan untuk merekam percakapan dan situasi dengan subjek sehingga catatan lapangan yang dibuat mendapatkan informasi yang lebih lengkap dan detail.

\section{Kredibilitas Penelitian}

Ada beberapa cara meningkatkan kredibilitas data terhadap hasil penelitian kualitatif antara lain perpanjangan pengamatan, peningkatan ketekunan dalam penelitian, triangulasi, diskusi dengan teman sejawat, analisis kasus negatif, dan mengadakan member check (Sugiyono, 2016). Upaya yang dilakukan dalam meningkatkan kredibilitas penelitian adalah perpanjangan pengamatan, meningkatkan ketekunan, triangulasi, menggunakan bahan referensi, dan mengadakan member check.

\section{Isu Etik}

Dalam setiap penelitian, terdapat isu-isu etis yang harus diperhatikan, untuk mengurangi konsekuensi dari pelanggaran isu etis, perlu adanya penerapan sistem-sistem seperti pemberian informed consent diawal wawancara untuk mendapat persetujuan subjek, menjaga kerahasiaan dan anonimitas, mengurangi kemungkinan munculnya konsekuensi negatif penelitian, serta memerhatikan posisi dan peran peneliti.

Dalam penelitian ini, peneliti menggunakan kontrak sosial berupa informed consent yang merupakan pedoman dari kode etik psikologi Indonesia yaitu pada pasal 49 mengenai informed consent. Informed consent bersifat resmi dan berlandaskan hukum serta disepakati oleh kedua belah pihak, yaitu subjek dan peneliti. Pemberian informed consent ini bertujuan untuk mengantisipasi terjadinya konsekuensi negatif dalam penelitian atau mencegah adanya perlakuanperlakuan yang dirahasiakan yang dapat merugikan subjek.

Dalam informed consent, peneliti menjelaskan deskripsi dan prosedur penelitian, kemungkinan-kemungkinan yang dapat terjadi selama proses penelitian serta hak-hak subjek penelitian selama penelitian ini berlangsung. Subjek yang 
telah menyetujui informed consent tersebut kemudian memiliki tanggung jawab etis untuk memberikan informasi sejelas-jelasnya dan sebenar-benarnya sepanjang informasi tersebut tidak mengganggu privasi serta tidak berisiko mencederai subjek penelitian, baik secara fisik maupun secara sosial (Himpsi, 2010).

\section{HASIL PENELITIAN}

Penelitian ini dibagi ke dalam tiga kategori yaitu kategori 1 yaitu gaya hidup hedonisme yang terdiri dari bentuk gaya hidup hedonisme dan faktor yang memengaruhi gaya hidup hedonisme, kategori 2 yaitu proses mengikuti gaya hidup hedonisme terdiri dari hambatan dan upaya, dan yang terakhir adalah kategori 3 yaitu motivasi mengikuti gaya hidup hedonisme yang terdiri dari dari dalam diri (intrinsik), dan luar diri (ekstrinsik).

Kategori 1. gaya hidup hedonisme

Bentuk gaya hidup hedonisme berdasarkan informasi dari ketujuh subjek dapat dijelaskan dalam tiga aspek yaitu yang pertama aktivitas, yang kedua minat, dan yang terakhir adalah opini.

Aspek aktivitas adalah perilaku yang dan diwujudkan dalam tindakan atau perilaku nyata yang dapat dilihat. Ketujuh subjek memiliki kecenderungan aktivitas yang berbeda-beda, dan aktivitas yang terlihat dari ketujuh subjek menunjukkan kecenderungan menghabiskan uang saku atau uang beasiswa untuk hal yang dapat dikatakan hanya kesenangan sesaat dan bukan termasuk kebutuhan bahkan lebih pada keinginan. Ketujuh rata-rata menghabiskan waktunya untuk nongkrong di tempat mewah dan sedang menjadi tren, membeli barang yang kurang diperlukan, dan melakukan berbagai cara untuk dapat memenuhi keinginan yang hanya untuk menaikkan citra diri.

Aspek minat yaitu muncul pada suatu objek, peristiwa atau topik yang menekankan pada kesenangan hidup. Ketujuh subjek memiliki minat yang cenderung mementingkan merek terhadap benda atau hobi yang dimiliki, dan harga dari benda tersebut dapat dikatakan mahal jika dilihat dari sosial ekonomi masing-masing subjek yang faktanya menerima beasiswa BIDIKMISI.

Aspek opini adalah pendapat atau wawasan mengenai isu-isu sosial dan produk yang sedang menjadi tren dan menjadi fokus yang subjek ikuti. Ketujuh subjek rata-rata mengikuti perkembangan fashion dan expert dalam bidang yang ketujuh subjek tekuni yang juga berkaitan untuk mencapai kesenangan dan menaikkan citra diri.

Berdasarkan informasi yang didapat di lapangan, faktor keluarga memengaruhi bagaimana kecenderungan gaya hidup hedonisme pada ketujuh subjek. Keluarga mengambil alih yang penting dalam pemilihan gaya hidup ketujuh subjek. Keluarga merupakan lingkungan pertama yang dilihat dan dikenal oleh individu, otomatis keluarga menjadi hal yang penting untuk bagaimana seseorang dapat hidup untuk kedepannya. Ketujuh subjek dari hasil wawancara dan observasi mengatakan bagaimana kondisi keluarganya dan memengaruhi bagaimana kecenderungan gaya hidup hedonisme masing-masing subjek. Ketujuh subjek tidak memiliki hubungan yang dekat dengan keluarga khususnya orangtua dan terkesan dibebaskan oleh orangtua yang mendorong kecenderungan gaya hidup hedonisme. Ketujuh subjek juga tidak mendapatkan pemenuhan kebutuhan materi yang cukup dari orangtua ketujuh subjek.

Berdasarkan informasi yang didapat di lapangan, ketujuh subjek banyak terpengaruh oleh teman sepermainan di dalam dataupun di luar kampus yang mendorong kecenderungan gaya hidup hedonisme seperti pujian dan ingin mengikuti tren dari teman. Teman sepermainan mengambil peranan penting karena subjek berada pada masa remaja yaitu lebih banyak menghabiskan waktu bersama teman dibandingkan dengan individu lain.

Pengaruh yang kedua adalah dari pacar, sebagain besar subjek dalam penelitian ini terpengaruh dengan hadirnya sosok pacar yang dikaitkan dengan kecenderungan gaya hidup hedonisme. Subjek melampiaskan emosi negatif untuk mencari kesenangan dengan pacar dan lebih sering bersama pacar daripada keluarga. Rata-rata subjek terpengaruh oleh gaya hidup pacar dan ingin terlihat setara dengan pacar yang ekonominya menengah ke atas. Hal tersebut terjadi karena di masa remaja, individu mulai berusaha mencari dan menyukai lawan jenis. Masa remaja juga masa pencarian identitas diri yang ingin menunjukkan diri menjadi sosok yang hebat dan tanpa batas, salah satunya ditunjukkan kepada pacar. Kategori 2. proses mengikuti gaya hidup hedonisme

Upaya yang dimaksud dalam penelitian ini adalah bagaimana subjek berusaha atau bagaimana usaha subjek untuk dapat mengikuti gaya hidup hedonisme. Usaha yang dilakukan masing-masing subjek berbeda-beda tergantung bagaimana bentuk kecenderungan gaya hidup hedonisme yang diikuti. Ketujuh subjek menggunakan dana BIDIKMISI untuk mengikuti kecenderungan gaya hidup hedonisme.

Hambatan yang dimaksud dalam penelitian ini adalah hal yang mempersulit subjek untuk mengikuti gaya hidup hedonisme. Ketujuh subjek memiliki hambatan yang sama yaitu dalam hal kekurangan dana untuk mengikuti gaya hidup hedonisme, selanjutnya hal tersebut juga berkaitan dengan tidak adanya persetujuan dari orangtua karena berasal dari ekonomi menengah ke bawah.

Kategori 3. motivasi mengikuti gaya hidup hedonisme

Berdasarkan informasi yang didapatkan di lapangan, ketujuh subjek memiliki alasan atau latar belakang untuk mengikuti gaya hidup hedonisme yaitu motivasi. Motivasi yang didapat dari wawancara dan observasi terhadap ketujuh subjek dapat dibagi menjadi dua yaitu motivasi yang berasal dari dalam diri (intrinsik) dan motivasi yang berasal dari luar diri (ekstrinsik). Berikut ini merupakan pemaparan motivasi ekstrinsik dan intrinsik dari ketujuh subjek:

Berasal dari luar diri (ekstrinsik)

Dari ketujuh subjek ditemukan informasi jika motivasi mengikuti gaya hidup hedonisme yang berasal dari luar diri antara lain:

1. Promosi

Subjek mengikuti gaya hidup hedonisme karena termotivasi untuk mempromosikan benda mewah yang dimiliki, hal tersebut dilakukan untuk menarik perhatian teman atau orang lain agar menggunakan produk atau jasa yang subjek jual. 


\section{Kepercayaan}

Kepercayaan yang dimaksud adalah subjek termotivasi untuk membuat orang lain percaya terhadap subjek. Subjek mempunyai motivasi yang sama yaitu ingin membangun kepercayaan terhadap orang lain yang nantinya akan membeli atau menggunakan jasanya.

3. Penyetaraan

Penyetaraan dalam hal ini adalah subjek termotivasi untuk mengikuti gaya hidup hedonisme karena ingin setara dengan sosial ekonomi orang lain atau orang terdekat subjek.

4. Pengakuan

Pengakuan dalam hal ini adalah subjek termotivasi untuk mengikuti gaya hidup hedonisme karena menginginkan pengakuan dari orang lain atau orang terdekat subjek.

5. Relasi

Relasi dalam hal ini adalah subjek termotivasi mengikuti gaya hidup hedonisme agar memiliki hubungan yang lebih baik dengan orang lain.

6. Model

Model dalam hal ini adalah subjek termotivasi mengikuti gaya hidup hedonisme agar menjadi model atau contoh untuk orang lain.

7. Terkenal

Terkenal dalam hal ini adalah subjek termotivasi mengikuti gaya hidup hedonisme agar dikenal oleh banyak orang.

8. Role model

Subjek termotivasi mengikuti gaya hidup hedonisme karena untuk mengikuti idola masing-masing. Subjek ingin terlihat sama dengan idola dengan mengikuti apa yang idola pakai atau lakukan.

9. Penampilan

Penampilan yang dimaksud adalah subjek mengikuti gaya hidup hedonisme yaitu termotivasi untuk menunjang penampilan dan mendapat pujian dari orang lain.

Berasal dari dalam diri (intrinsik)

1. Percaya Diri

Subjek termotivasi mengikuti gaya hidup hedonisme untuk menaikkan dan menunjang rasa percaya diri.

2. Karier

Subjek termotivasi mengikuti gaya hidup hedonisme karena ingin menunjang karier yang berhubungan dengan kepentingan diri sendiri.

\section{HASIL PENELITIAN}

Kerangka hasil penelitian dapat dilihat pada gambar 1 (terlampir).

\section{PEMBAHASAN DAN KESIMPULAN}

Gaya hidup hedonisme adalah salah satu jenis gaya hidup yang memiliki pandangan kenikmatan dan kesenangan sebagai tujuan dalam hidup (Ajeng, 2010). Gaya hidup hedonisme lebih banyak diikuti oleh remaja dengan ekonomi menengah ke atas, hal tersebut dikarenakan remaja dengan ekonomi menengah keatas memiliki modal untuk mengikuti kecenderungan tersebut (Sari, 2014).

Pada tahap perkembangan remaja, individu sedang berada pada fase pencarian identitas diri. Remaja akan merasa takut gagal, gelisah, dan tertekan akan stigma yang diberikan oleh orang lain sebagai individu yang tertinggal oleh zaman jika tidak mengikuti tren. Hal tersebut yang menjadi salah satu penyebab kecenderungan gaya hidup hedonisme lebih banyak diikuti oleh remaja, salah satunya adalah mahasiswa. Hal tersebut pasti ada yang memotivasi atau mendorong (Trimartati, 2014).

Berdasarkan studi pendahuluan yang telah dilakukan di Universitas Udayana yang merupakan universitas favorit di Provinsi Bali, salah satu sosiolog mengatakan jika mahasiswa Universitas Udayana saat ini lebih memilih untuk memenuhi gaya hidup daripada kebutuhan hidup, dan menampilkan eksistensi masyarakat tontonan yang saling menonton satu sama lain, lebih jelasnya yaitu mahasiswa lebih menampilkan simbol pada dirinya dengan mengutamakan "merek" seperti merek pakaian, sepatu, gadget, dan lain-lain yang dapat memperlihatkan citra diri dan eksistensi seorang mahasiswa. WN mengatakan jika hal tersebut dipengaruhi oleh banyaknya mall atau pusat perbelanjaan yang ada di Bali, yang mendorong masyarakat untuk berperilaku konsumtif yang merupakan salah satu ciriciri masyarakat yang memiliki kecenderungan gaya hidup hedonisme (Buana \& Tobing, 2017).

Studi pendahuluan selanjutnya dilakukan terhadap mahasiswi yang menerima beasiswa BIDIKMISI melalui wawancara mendalam, didapatkan hasil jika mahasiswi Universitas Udayana yang menerima beasiswa BIDIKMISI memiliki kecenderungan gaya hidup hedonisme yaitu ditinjau berdasarkan tiga aspek dari Amstrong (2003) yaitu aktivitas seperti lebih banyak menghabiskan waktu di luar rumah dengan nongkrong di pusat perbelanjaan atau kafe bersama teman dan orang terdekat, kemudian minat seperti selalu mengikuti tren, mengoleksi barang-barang mewah dan kepemilikan gadget canggih, dan terakhir adalah opini yaitu selalu mengetahui tren atau informasi terkini (Buana \& Tobing, 2017).

Pada penelitian ini didapatkan jika bentuk gaya hidup hedonisme dibagi menjadi tiga aspek menurut Kotler \& Philip (2009) yaitu aktivitas, minat, dan opini. Aktivitas dalam hal ini mengacu pada bagaimana individu menggunakan waktunya dengan tindakan nyata seperti lebih banyak menghabiskan waktu di luar rumah, membeli barangbarang yang kurang diperlukan, pergi ke pusat perbelanjaan dan kafe. Minat dalam hal ini adalah apa yang dianggap menarik dari suatu lingkungan individu yang dapat muncul terhadap suatu objek, peristiwa atau topik yang menekankan pada kesenangan hidup seperti fashion, makanan, bendabenda mewah, tempat berkumpul dan selalu ingin menjadi pusat perhatian, yang terakhir yaitu opini adalah pendapat seseorang yang diberikan dalam merespon situasi ketika muncul pertanyaan-pertanyaan atau isu sosial dan produk yang berkaitan dengan hidup, opini juga digunakan untuk mendeskripsikan pemikiran, harapan dan evaluasi dalam perilaku.

Ketujuh subjek rata-rata senang melakukan aktivitas nongkrong di kafe dan pusat perbelanjaan seperti mall, 
membeli barang yang kurang diperlukan yaitu hanya sebatas keinginan dan bukan termasuk kebutuhan seperti barang elektronik, dan benda mewah lain. Berdasarkan aspek minat, ketujuh subjek menunjukkan bentuk gaya hedonisme antara lain lebih mementingkan merek dalam pembelian barang, senang jika menggunakan barang yang mewah dan harganya mahal, mengikuti tren fashion, dan mengoleksi barang mewah. Aspek terakhir yaitu membahas mengenai opini dari ketujuh subjek, di dalam penelitian ini subjek memiliki opini yang berbeda-beda tergantung dengan apa yang sedang ditekuni seperti fokus pada fashion, teknologi, musik, dan hobi.

Hal tersebut juga sejalan dengan penjelasan dari Rianton (2012) yang menjelaskan bahwa gaya hidup hedonisme adalah pola yang dapat diidentifikasi dari aktivitas, minat dan opini yang cenderung mengarah dan menekankan pada kesenangan hidup. Penjelasan tersebut dapat menjadi indikator jika ketujuh subjek memiliki kencenderungan gaya hidup hedonisme yaitu mengarah pada kesenangan hidup.

Temuan selanjutnya adalah terkait faktor yang memengaruhi gaya hidup hedonisme yaitu menurut Kotler (2009) yaitu faktor ekstrinsik mengenai pengaruh kelompok referensi yaitu keluarga, teman dan pacar. Faktor keluarga dapat dikatakan sangat penting karena sikap, perilaku dan gaya hidup seseorang dipengaruhi oleh faktor keluarga. Hal tersebut karena pola asuh keluarga yang membentuk kebiasaan anak yang secara logika merupakan pola hidupnya. Berdasarkan hasil penelitian, ketujuh subjek cenderung dibebaskan dan memiliki hubungan yang tidak dekat dengan orangtua yang menyebabkan subjek mencari perhatian lain dengan mengikuti gaya hidup hedonisme.

Temuan tersebut juga sejalan dengan hasil dari penelitian Trimartati (2014) yang menjelaskan jika faktor orangtua menjadi salah satu faktor yang paling bertanggung jawab dalam mengontrol pola perilaku mahasiswa, kebebasan yang diberikan orangtua dan kurangnya kontrol dari orangtua yang disalahartikan sebagai dorongan untuk mengikuti gaya hidup hedonisme seperti yang dialami ketujuh subjek. Teori dari Asrori dan Ali (2015) juga menjelaskan jika anak yang merasa jika tidak dihargai dan tidak merasa dilindungi oleh orangtua akan memengaruhi perkembangan emosional yaitu ketidakstabilan emosi yang menyebabkan anak memilih cara instan untuk dapat mencari perlindungan atau kebahagiaan lain yang jika dikaitkan dengan penelitian ini adalah mengikuti kecenderungan gaya hidup hedonisme. Hubungan yang kurang harmonis dengan keluarga terutama orangtua juga memengaruhi perkembangan nilai, moral dan sikap untuk dasar pemilihan gaya hidup.

Teori lain yang sejalan adalah dari Hurlock (2011) yang menjelaskan mengenai pola asuh anak, yang jika dikaitkan dengan hasil penelitian ini adalah pola asuh permisif yang diterapkan orangtua ketujuh subjek dalam mendidik subjek. Pola asuh permisif cenderung membiarkan anak bertindak sesuai dengan keinginannya yaitu terkesan membebaskan dan kurangnya kontrol terhadap anak, hal tersebut yang dapat disalahgunakan oleh anak yang terjadi pada ketujuh subjek yaitu dengan mengikuti kecenderungan gaya hidup hedonisme. kurangnya perhatian dari orangtua menyebabkan ketujuh subjek mencari penyaluran emosi negatif melalui cara-cara yang didapatkan dari lingkungan.

Hasil penelitian dari ketujuh subjek juga menjelaskan jika tidak terpenuhinya kebutuhan yang bersifat psikis ataupun materi, menurut Ali dan Asrori (2015) memaparkan mengenai konsekuensi jika kebutuhan remaja yang tidak terpenuhi akan menimbulkan kekecewaan, ketidakpuasan, atau bahkan frustasi yang pada akhirnya mengarahkan anak pada hal yang bersifat negatif salah satunya mengikuti kecenderungan gaya hidup hedonisme sebagai usaha untuk mencapai kepuasan.

Faktor yang kedua adalah teman, menurut Kotler (2009) teman masuk dalam pengaruh utilitarian yang merupakan pengaruh kelompok acuan yang dapat diekspresikan melalui tekanan untuk mengikuti suatu aturan atau tren dalam kelompok. Pergaulan teman sebaya (peer group) sangat memengaruhi seseorang untuk mengikuti gaya hidup kelompok yang diikuti. Hal tersebut terjadi karena intensitas pertemuan dan perkembangan sosial pada individu khususnya remaja lebih banyak melibatkan teman sebaya (Santrock, 2007). Subjek rata-rata lebih banyak menghabiskan waktunya dengan teman sebaya, pengaruh dari teman yang dialami kelima subjek berbentuk pujian yang secara tidak langsung menguatkan perilaku gaya hidup hedonisme masing-masing subjek. Hal tersebut juga sejalan dengan teori dari Hasibuan \& Moedjiono (2008) yang menjelaskan mengenai pujian sebagai penguatan yang bersifat verbal yang secara tidak langsung menguatkan tingkah laku individu dalam konteks ini adalah pujian ketika kelima subjek membawa atau memakai benda mewah dan bermerek yang mendorong kecenderungan gaya hidup hedonisme.

Faktor yang ketiga berasal dari pacar yaitu rata-rata ketujuh subjek juga lebih dekat dengan pacar daripada keluarga. Subjek yang berada pada tahap perkembangan remaja madya menurut teori dari Ali dan Asrori (2015) mengatakan jika remaja sedang benar-benar memulai jatuh cinta dengan lawan jenis. Gejala tersebut terkadang membawa dampak yang negatif seperti konflik dan gangguan emosi ketika terganggu pada percintaannya atau terlalu mengikuti arus percintaan. Teori yang sejalan dengan hal tersebut adalah teori dari Syafaati (2008) yang menjelaskan mengenai faktor-faktor yang memengaruhi gaya hidup hedonisme berasal dari faktor eksternal yaitu salah satunya sosok pacar dan kurangnya perhatian dari orangtua. Hurlock (2011) juga menjelaskan mengenai remaja yang tergolong mahasiswa dalam kesehariannya lebih sering menghabiskan waktu dengan teman dan pacar yang tidak dapat dipungkiri jika pengaruh teman dekat atau pacar cenderung akan diikuti seperti yang terjadi dengan subjek.

Temuan berikutnya adalah upaya dan hambatan yang dilakukan mahasiswa penerima beasiswa BIDIKMISI untuk mengikuti gaya hidup hedonisme, berdasarkan hasil penelitian upaya yang dilakukan subjek rata-rata adalah 
menggunakan uang BIDIKMISI, berhutang, meminjam benda mewah orang lain, dan mementingkan keinginan daripada kebutuhan. Menurut Dewojati (2010), gaya hidup hedonisme merupakan gaya hidup yang menganggap bahwa kesenangan dan kenikmatan materi sebagai tujuan hidup, oleh karena itu individu yang menganut gaya hidup hedonisme selalu berusaha dan melakukan berbagai upaya untuk dapat memuaskan hasrat yang ingin dicapai. Pendapat lain yang sejalan dengan hal tersebut adalah dari Hamzah (2016) yang menjelaskan jika upaya merupakan unsur intensitas yaitu apabila individu termotivasi dalam melakukan sesuatu atau keinginan individu tersebut akan mencoba sekuat tenaga, agar upaya tersebut mendapatkan hasil yang memuaskan. Penelitian dari Trimartati (2014) juga menjelaskan beberapa dampak negatif dari perilaku hedonisme yaitu gaya hidup shopaholic antara lain kehabisan uang walaupun masih awal bulan, yang menyebabkan individu mengambil jalan pintas seperti menggunakan uang yang bukan hak, berhutang, atau membeli barang yagn sebenarnya bukan kebutuhan dan hanya sebatas keinginan untuk suatu kepuasan. Berdasarkan pemaparan tersebut dapat disimpulkan jika upaya yang dilakukan subjek dalam penelitian ini rata-rata bersifat negatif yang tujuannya adalah untuk mengikuti kecenderungan gaya hidup hedonisme.

Hambatan yang diperoleh dalam mengikuti gaya hidup hedonisme berdasarkan hasil penelitian adalah kurangnya dana yang otomatis juga membuat orangtua tidak setuju. Mahasiswa penerima beasiswa BIDIKMISI adalah mahasiswa yang dikategorikan tidak mampu yaitu masuk dalam kelas ekonomi menengah kebawah dan dianggap memiliki potensi akademik (Kemenristek, 2017). Sejalan dengan definisi tersebut, mahasiswa penerima beasiswa BIDIKMISI akan selalu kekurangan dana dan tidak ada persetujuan dari orangtua karena berasal dari keluarga dengan ekonomi menengah kebawah dan masih banyak keperluan yang harus dipenuhi daripada membeli barang mewah dan bermerek hanya untuk keinginan dan kepuasan saja.

Temuan selanjutnya adalah motivasi mahasiswa penerima beasiswa BIDIKMISI untuk mengikuti gaya hidup hedonisme, berdasarkan hasil penelitian berasal dari dalam diri (intrinsik) antara lain percaya diri dan karier selanjutnya luar diri (ekstrinsik) antara lain promosi, kepercayaan, penyetaraan, model, pengakuan dan relasi, terkenal, role model dan penampilan.

Berdasarkan sumbernya, motivasi dapat dibagi menjadi dua yaitu motivasi intrinsik (dari dalam diri) dan ekstrinsik (dari luar diri). Motivasi intrinsik timbulnya tidak memerlukan rangsangan dari luar karena memang telah ada dalam diri individu, motivasi intrinsik lebih kuat dibandingkan motivasi ekstrinsik karena berasal dari niat dan minat dari diri individu yang tidak ada sangkut pautnya dengan paksaan atau pengaruh orang lain. Motivasi intrinsik adalah motivasi yang dikaitkan dengan pemaknaan dan peranan kognisi seperti minat dan keingintahuan, hal tersebut membuat individu tidak lagi termotivasi oleh bentuk-bentuk insentif atau hukuman.
Motivasi ekstrinsik timbul karena adanya rangsangan dari luar. Motivasi ekstrinsik disebabkan oleh keinginan untuk menerima ganjaran atau menghindari hukuman atau dapat dikatakan jika motivasi ekstrinsik adalah motivasi yang terbentuk dari faktor-faktor eksternal berupa ganjaran dan hukuman (Hamzah, 2016).

Motivasi intrinsik pertama adalah untuk menunjang rasa percaya diri, menurut penjelasan Amstrong (2003) pembelian benda-benda bermerek dan mewah tujuannya adalah untuk menunjukkan simbol bahwa individu tersebut masuk dalam kelas sosial ekonomi menengah keatas, subjek merasa lebih percaya diri ketika menggunakan benda mewah dan bermerek. Penjelasan yang sejalan yaitu dari Hurlock (2011) yang menjelaskan mengenai ciri-ciri masa remaja yaitu proses pencarian identitas diri dan jika dilihat dari temuan penelitian ini, subjek ingin menunjukkan siapa dirinya yang diperlihatkan melalui simbol dan bukan merupakan dirinya yang sebenarnya, dan semata-mata untuk menunjang rasa percaya diri subjek.

Motivasi intrinsik yang kedua yaitu karier, subjek termotivasi untuk mengikuti gaya hidup hedonisme dengan tujuan untuk menunjang kariernya yang rata-rata berkaitan dengan program studi yang diikuti, yang merupakan pilihan dari dalam diri subjek yang nantinya akan menentukan karier yang akan dicari. Menurut Hamzah (2016) tiga teori motivasi yaitu existence, relatedness, dan growth, karier masuk dalam teori pertumbuhan (growth) yaitu motivasi yang berhubungan dengan perkembangan potensi perorangan dengan kebutuhan akan penghargaan dan aktualisasi diri. Sejalan dengan hal tersebut, menurut Hurlock (2011) mahasiswa yang masuk dalam tahapan masa perkembangan remaja akhir sudah mampu untuk lebih selektif dalam memilih suatu hal. Berdasarkan hal tersebut motivasi subjek untuk menunjang karier dikatakan motivasi yang berasal dari dalam diri yang merupakan passion masing-masing subjek.

Motivasi ekstrinsik dalam penelitian ini yang pertama adalah ingin mengikuti idola atau mempunyai role model. Subjek termotivasi untuk mengikuti idola dan ingin menjadi seperti idola yang diinginkan. Menurut Amstrong (2003) mengikuti fashion atau tren saat ini merupakan salah satu aspek dalam gaya hidup hedonisme yang tujuannya adalah untuk mencari kesenangan dan menunjukkan suatu simbol didepan individu lain. Motivasi ingin mengikuti idola pada subjek dalam penelitian ini termasuk pada aspek minat yaitu mengikuti tren fashion idola untuk kesenangan dan terlihat up to date.

Motivasi intrinsik yang kedua ingin menunjang penampilan berdasarkan hasil temuan, motivasi tersebut berasal dari luar diri subjek karena subjek memang menyukai dan berminat untuk menunjang penampilan, yang mana menurut Santrock (2007) pada tahap perkembangan yaitu remaja, individu lebih mementingkan penampilan, hal tersebut juga sejalan dengan aspek gaya hidup hedonisme menurut Amstrong (2003) yang memaparkan mengenai aspek minat dari gaya hidup hedonisme yaitu fashion salah satunya adalah mementingkan penampilan. Subjek yang mementingkan 
penampilan cenderung memiliki perilaku pembelian kompulsif yang menurut Utami (2010) adalah respon terhadap dorongan yang tidak terkendali atau keinginan untuk memperoleh, menggunakan, atau mengalami suatu perasaan, substansi, atau kegiatan yang mendorong individu untuk melakukannya berulang kali, konsumen yang memiliki perilaku tersebut cenderung membeli barang secara berlebihan yang tidak diperlukan yang terkadang tidak mampu untuk dibeli, hal tersebut juga terjadi kepada subjek dalam penelitian ini yaitu membeli benda mewah yang kurang diperlukan.

Motivasi ekstrinsik yang ketiga dan keempat yang ada dalam temuan ini yaitu promosi dan kepercayaan. Jika dilihat dari teori Hamzah (2016) yaitu motivasi ekstrinsik terjadi karena ada penguatan dan hukuman, berdasarkan hal tersebut motivasi untuk menunjang promosi dan kepercayaan diikuti oleh subjek agar individu lain tertarik untuk menggunakan jasa subjek yang berkaitan dengan karier yang akan diambil kemudian hari atau yang sedang dikerjakan saat ini. Hal tersebut juga sejalan dengan teori motivasi kebutuhan dari Abraham Maslow (dalam Hamzah, 2016) yang menjelaskan mengenai kebutuhan akan kemitraan atau kebutuhan sosial yaitu kebutuhan untuk memiliki hubungan dengan individu lain atau kelompok lain, kebutuhan tersebut juga dinilai dari pekerjaan seperti promosi dan menginginkan kepercayaan dari orang lain dengan dasar hubungan kemitraan sosial yang ditimbulkannya.

Motivasi ekstrinsik kelima adalah relasi yaitu subjek termotivasi untuk mengikuti gaya hidup hedonisme untuk menambah, memperluas atau menguatkan relasi terhadap suatu kelompok atau individu lain. Motivasi ini juga berkaitan dengan Santrock (2007) yang menjelaskan jika masa remaja adalah masa untuk ingin mencari relasi seluasluasnya dan tanpa batas, hal tersebut juga sejalan dengan penjelasan Rianton (2012) yaitu mengenai ciri-ciri individu yang mengikuti kecenderungan gaya hidup hedonisme yang selalu ingin berkumpul atau nongkrong dengan teman-teman dan menyukai aktivitas di luar rumah untuk menambah relasi. Teori lain yang berhubungan dengan motivasi kebutuhan akan relasi adalah menurut Hamzah (2016) yang menjelaskan mengenai keterkaitan dengan hubungan kemitraan, yang bercermin dari teori yang menjelaskan jika manusia adalah makhluk sosial yang tidak dapat hidup dengan sendirinya. Setiap individu mengaitkan keberadaannya dengan orang lain dan dengan lingkungannya, interaksi dan keterkaitan sangat penting untuk suatu makna yang hakiki, selanjutnya teori manusia kompleks dari Hamzah (2016) menjelaskan mengenai teori manusia sosial yang motivasinya dipengaruhi terumata oleh sifat hubungan kemitraan, hal tersebut yang mendorong subjek dalam penelitian ini untuk mengikuti gaya hidup hedonisme.

Motivasi ekstrinsik keenam dan ketujuh adalah penyetaraan dan pengakuan yaitu subjek termotivasi agar bisa setara dengan suatu kelompok atau individu lain untuk mendapatkan pengakuan. Menurut teori motivasi kebutuhan dari Maslow (dalam Hamzah, 2016) menjelaskan mengenai salah satu kebutuhan dalam hidup ini adalah kebutuhan akan penghargaan antara lain yaitu penyetaraan dan pengakuan, oleh karena itu subjek dalam penelitian ini mengikuti gaya hidup hedonisme untuk dianggap setara dan mendapatkan pengakuan seperti penghargaan dari individu lain. Teori lain yang berkaitan dengan motivasi ini adalah dari Hurlock (2011) yang menjelaskan jika menurut tahap perkembangannya, subjek termasuk dalam tahap perkembangan remaja yang lebih banyak menghabiskan waktunya bersama teman sebaya atau kelompok sepermainan, subjek berusaha untuk melakukan berbagai usaha agar dapat setara dan mendapat pengakuan di dalam kelompok teman sebaya atau individu lain.

Motivasi ekstrinsik kedelapan adalah ingin menjadi model atau panutan untuk orang lain, menurut penjelasan Amstrong (2003) mengenai aspek gaya hidup hedonisme yang berkaitan dengan minat yaitu ingin menjadi pusat perhatian, subjek termotivasi mengikuti gaya hidup hedonisme untuk menjadi pusat perhatian bagi kelompok lain atau orang lain. Motivasi tersebut juga berkaitan dengan teori dari Abraham Maslow (dalam Hamzah, 2016) yaitu kebutuhan akan penghargaan atau pengakuan dari orang lain untuk dijadikan model atau panutan.

Motivasi ekstrinsik kesembilan adalah ingin menjadi terkenal yang juga berkaitan dengan penjelasan motivasi sebelumnya yaitu ingin menjadi pusat perhatian. Subjek dalam penelitian mengikuti gaya hidup hedonisme untuk menjadi terkenal, hal tersebut berhubungan dengan teori kebutuhan akan eksistensi dari Alderfer (dalam Hamzah, 2016) yang mengatakan kebutuhan tersebut keterkaitan dengan keberadaan manusia yang dipertahankan. Pada intinya, subjek dalam penelitian ini ingin tetap eksis dan terkenal yaitu dengan mengikuti gaya hidup hedonisme.

\section{DAFTAR PUSTAKA}

Ajeng \& Nuryanti. (2010). Hubungan kontrol diri terhadap gaya hidup hedonisme pada remaja. Skripsi. Fakultas Psikologi Universitas Muhammadiyah Surakarta. Diakses dari http://eprints.ums.ac.id

Amstrong, K. (2003). Dasar-dasar pemasaran. Jakarta: PT. Indeks Gramedia

Asrori \& Ali. (2015). Psikologi remaja. Jakarta: PT. Bumi Aksara.

Chaney. (2010). Lifestyle: Sebuah pengantar komprehensif. Yogyakarta: Jalasutra

Creswell, J. W. (2009). Research design pendekatan penelitian kualitatif, kuantitaif, dan mixed. Yogyakarta: Pustaka Pelajar.

Departemen Pendidikan Indonesia (2008). Kamus Besar Bahasa Indonesia. Jakarta: Balai Pustaka.

Dewojati. (2010). Wacana hedonisme. Yogyakarta: Pustaka Pelajar.

Hamzah. (2016). Teori motivasi dan pengukurannya: Analisis di bidang pendidikan. Jakarta: PT. Bumi Aksara.

Handayani \& Patricia. (2014). Pengaruh gaya hidup hedonis terhadap perilaku konsumtif pada pramugari maskapai penerbangan "x". Jurnal Fakultas Psikologi Esa Unggul, 12(1), 85-97. Diakses dari https://media.neliti.com

Himpunan Psikologi Indonesia. (2010). Kode etik psikologi Indonesia. Jakarta: Pengurus Pusat Himpunan Psikologi Indonesia. 
Hurlock, E. B. (2011). Psikologi perkembangan: Suatu pendekatan sepanjang rentang kehidupan. Jakarta: Erlangga.

Hasibuan \& Moedjiono. (2008). Proses belajar mengajar. Bandung: PT. Rosdakarya

Kemenristek [Bidikmisi]. (2017). Syarat-syarat Bidikmisi. Diakses dari https://bidikmisi.belmawa.ristekdikti.go.id/2017/11/syarat -syarat-mengikuti-bidikmisi.

Kunto. (2011). Kecil bahagia, muda foya-foya, tua kaya raya, mati maunya masuk surga. Yogyakarta: Kanisius.

Kotler \& Philip. (2009). Manajemen pemasaran. Jakarta: Erlangga.

Moelong \& Lexy. (2016). Metodologi penelitian kualitatif. Bandung: PT. Remaja Rosdakarya.

Paramita. (2015). Pengaruh motivasi belanja hedonik terhadap pembelian impulsif konsumen matahari Surabaya. Jurnal Ilmu dan Riset Manajemen Sekolah Tinggi Ilmu Ekonomi Indonesia Surabaya, 4(1), 86-98. Diakses dari https://ejournal.stiesia.ac.id

Pitana \& Diarta. (2003). Pengantar ilmu pariwisata. Yogyakarta: CV. Andi Offset

Rianton. (2012). Hubungan antara konformitas kelompok teman sebaya dengan gaya hidup Hedonis pada mahasiswa Kab. Dhamasraya di Yogyakarta. Empathy Jurnal Fakultas Psikologi. Yogyakarta: Universitas Ahmad Dahlan, 2(1), 1-15. Diakses dari http://www.jogjapress.com

Kemenristek [Bidikmisi]. (2017). Syarat-syarat Bidikmisi. Diakses dari https://bidikmisi.belmawa.ristekdikti.go.id/2017/11/syarat -syarat-mengikuti-bidikmisi.

Santrock, J. W. (2007). Adolescence, eleventh edition. United Kingdom: Erlangga.

Sari. (2014). Peran gaya hidup hedonisme dan locus of control dalam menjelaskan kecenderungan shopping addiction pada remaja putri di Program Studi Psikologi fakultas Ilmu Sosial dan Ilmu Politik Universitas Brawijaya. Skripsi. Universitas Brawijaya. Diakses dari http://psikologi.ub.ac.id

Setiadi. (2013). Perilaku konsumen: Perspektif kontemporer pada motif, tujuan, dan keinginan konsumen. Jakarta: Kencana Prenada Media Group.

Setiadi. (2014). Pengaruh globalisasi dalam hubungan internasional. Skripsi. Fakultas Ilmu Sosial dan Ilmu Politik Program Studi Hubungan Internasional Universitas Satya Negara Indonesia. Diakses dari https://isip.usni.ac.id

Sinthia. (2011). Hubungan antara penerimaan sosial kelompok kelas dengan kepercayaan diri pada siswa kelas I SLTP XXX Jakarta. Jurnal FKIP Universitas bengkulu, 14(1), 25-37. Diakses dari http://repository.unib.ac.id

Sugiyono. (2016). Metode penelitian kombinasi (Mixed Methods). Bandung: Alfabeta.

Syafaati. (2008). Dugem: Gaya hidup hedonis di kalangan anak muda. Skripsi. Diakses dari http://eprints.ums.ac.id

Trimartati. (2014). Studi kasus mengenai gaya hidup hedonisme mahasiswa bimbingan dan konseling Universitas Ahmad Dahlan. Jurnal Universitas Ahmad Dahlan, 3(1), 17-20. Diakses dari http://journal.uad.ac.id

Utami. (2010). Manajemen ritel (Strategi dan implementasi operasional bisnis ritel modern di Indonesia). Jakarta: Salemba Empat. 


\section{LAMPIRAN}

Gambar 1

Kerangka Hasil Penelitian

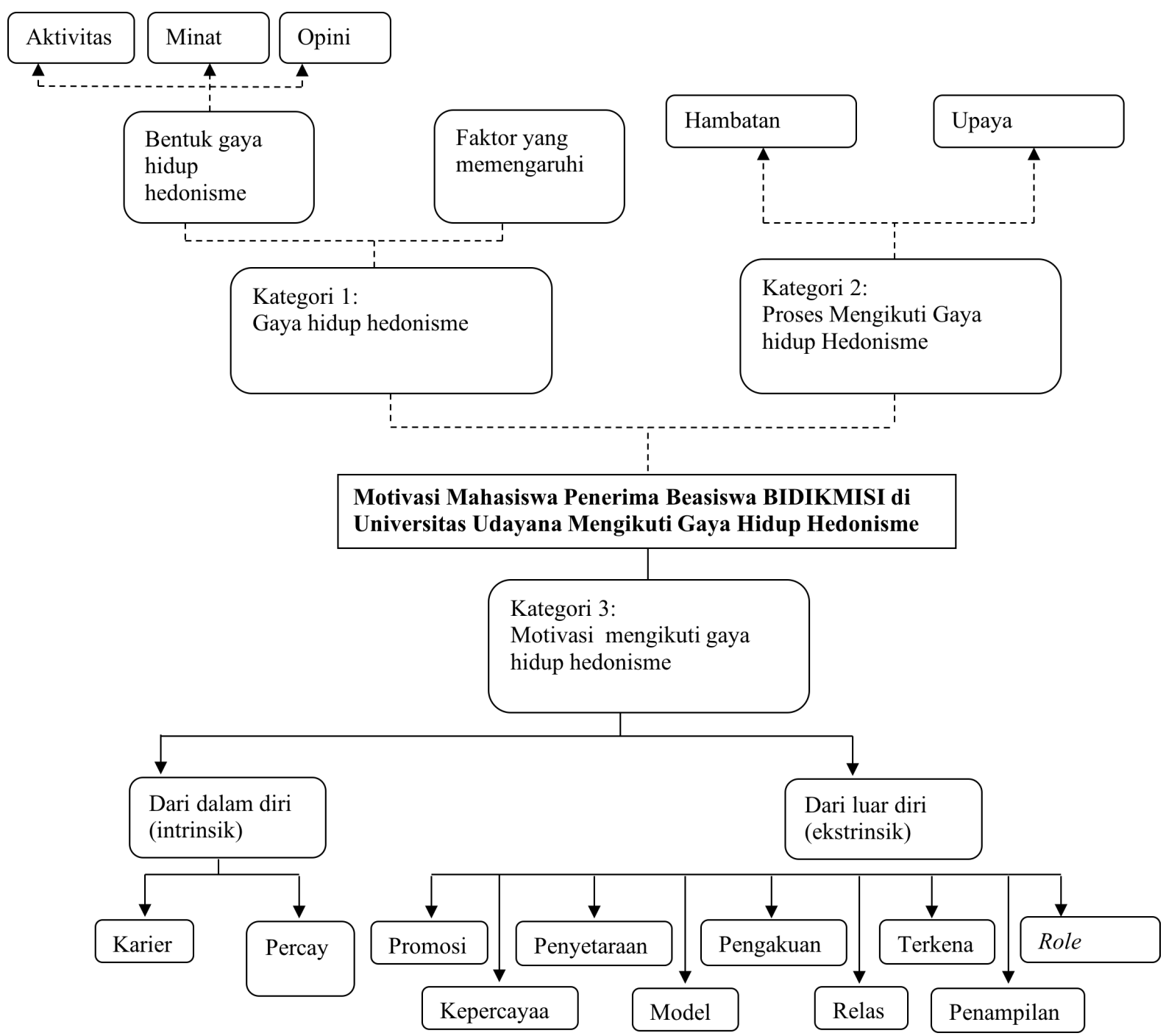

